\title{
PENGARUH KESADARAN MEMBAYAR PAJAK,PENGETAHUAN DAN PEMAHAMAN PERATURAN PERPAJAKAN,DAN KUALITAS LAYANAN TERHADAP KEMAUAN MEMBAYAR PAJAK WAJIB ORANG PRIBADI DI KOTA TOMOHON
}

\author{
Siska Lovihan \\ (Email : ska_lovi1988@yahoo.co.id)
}

\begin{abstract}
Tax is a State financial resources, including individual taxpayers who became a mainstay of the government to obtain funds to finance the implementation of the country. For taxpayers who performing independent personal services no parties are forced to pay taxes. They have a tax ID because of their own free will. This phenomenon is deemed interesting to be associated with factors that encourage people to pay taxes, therefore this study will discuss the influence of the tax paying awareness, knowledge and understanding of tax laws, and the quality of service to the willingness paying taxes an individual taxpayer.

Object of this study is the individual taxpayer who performing independent personal services registered in the Office of Counseling and Consultation Services Tax Tomohon the number of samples 77.

$T$ test used in hypothesis testing, to determine whether the independent variables significantly partially or not on the dependent variable and to determine the effect of independent variables on the dependent variable simultaneously used $F$ test.

Of the research that has been done, it is known that partial paying taxes awareness, and the quality of service significantly influence willingness paying taxes individual taxpayer in the city of Tomohon. While knowledge and understanding of tax laws do not significantly affect the willingness paying taxes an individual taxpayer in Tomohon. Taken together, paying taxes awareness, knowledge and understanding of tax laws, and the impact of service quality on willingness paying taxes individual taxpayer in Tomohon City.
\end{abstract}

Keyword : Pajak

\section{Pendahuluan}

\subsection{Latar Belakang Masalah}

Perpajakan merupakan salah satu kegiatan pemerintah berkaitan dengan pengelolaan keuangan negara yang berasal dari iuran masyarakat yang mempunyai tujuan untuk meningkatkan kesejahteraan rakyat melalui perbaikan dan penambahan pelayanan publik sehingga pemerataan dan peningkatan kesejahteraan masyarakat dapat tercapai serta mengurangi kesenjangan sosial antar penduduk.

Upaya atas pencapaian tujuan perpajakan itu sendiri tentu tidak selalu berjalan lancar. Salah satu hal yang perlu diperhatikan yaitu pemungutan pajak. Banyak faktor yang membuat para Wajib Pajak tidak membayar atau tidak melaporkan kewajiban pajaknya kepada petugas pajak. Dari Laporan Tahunan 2011 Direktorat Jenderal Pajak Sampai dengan tanggal 31 Desember 2011, jumlah wajib pajak orang pribadi terdaftar adalah 19,9 juta wajib pajak. Jumlah SPT Tahunan Orang Pribadi yang disampaikan berjumlah 8,5 juta. Sedangkan berdasarkan data Badan Pusat Statistik, jumlah orang yang aktif bekerja di Indonesia adalah 110 juta. Artinya, rasio wajib pajak orang pribadi terdaftar dan SPT Tahunan yang disampaikan terhadap kelompok pekerja aktif hanya mencapai $18,1 \%$ dan $7,73 \%$. Dengan kata lain tingkat kepatuhan wajib pajak orang pribadi masih rendah.

Kesadaran wajib pajak dalam membayar kewajibannya merupakan hal penting dalam penarikan pajak tersebut,suatu hal yang paling menentukan dalam keberhasilan pemungutan pajak adalah kemauan wajib pajak untuk membayar kewajiban pajaknya. Upaya-upaya yang dilakukan oleh pemerintah baik upaya pendidikan,penyuluhan dan sebagainya ,tidak akan berarti banyak dalam 
membangun kesadaran wajib pajak untuk membayar pajak, jika pemerintah tidak melakukan sosialisasi terhadap sistem perpajakan yang memadai dan mudah dipahami oleh masyarakat terutama para wajib itu sendiri.

Sistem pemungutan pajak dengan menggunakan Self Assessment memberikan peran aktif Wajib Pajak untuk melakukan sendiri perhitungan pajak terutang, menyetorkan sendiri, dan melaporkan SPT sendiri. Sistem ini lebih ditekankan kepada kerelaan Wajib Pajak untuk mematuhi kewajiban perpajakannya (Devano dan Rahayu ,2006:113). Untuk menunjang dari Self Assessment System tersebut Direktorat Jenderal Pajak membuat suatu sistem pendukung yang diharapkan dapat memudahkan Wajib Pajak dalam membayar dan melaporkan kewajiban pajaknya yaitu adanya $e$ filling, e-SPT, e-NPWP, e-regristration, drop box dan e-banking. Hal tersebut diharapkan dapat meningkatkan penerimaan pada sektor pajak dan dapat menciptakan suatu sudut pandang yang positif terhadap Direktorat Jenderal Pajak dan pada pajak itu sendiri.

Kemauan Wajib Pajak dalam membayar pajak adalah hal yang penting dalam penarikan pajak. Masyarakat sendiri dalam kenyataannya tidak suka membayar pajak. Hal ini disebabkan masyarakat tidak pernah tahu wujud konkret imbalan dari uang yang dikeluarkan untuk membayar pajak (Widayati dan Nurlis, 2010). Salah satu upaya dalam meningkatkan penerimaan pajak adalah dengan memberikan suatu pelayanan yang bermutu terhadap Wajib Pajak selaku pelanggan. Masih ada wajib pajak yang menunggu ditagih baru membayar pajak, seperti peraturan pajak pada periode lama . Dalam Supadmi,2009 Peningkatan kualitas dan kuantitas pelayanan diharapkan dapat meningkatkan kepuasan kepada Wajib Pajak sebagai pelanggan.

Kota Tomohon adalah salah satu kota di Provinsi Sulawesi Utara, Indonesia. Sebelum tahun 2003, Kota Tomohan merupakan salah satu kecamatan di Kabupaten Minahasa. Kota Tomohon mengalami banyak kemajuan sehingga ada penduduknya yang menginginkan Tomahan dipertingkatkan statusnya menjadi sebuah kota. Tomohon menjadi daerah kota yang disahkannya oleh Undang-undang RI Nomor 10 Tahun 2003 mengenai Pembentukan Kabupaten Minahasa Selatan dan Kota Tomohon di Provinsi Sulawesi Utara oleh DPR RI. Berkembangnya Kota Tomohon tentu seiring juga dengan meningkatnya penerimaan pajak di kota ini. Dimana Tomohon dikenal sebagai pusat pemborong sayur-sayuran dan pemborong bunga di Provinsi Sulawesi. Keistimewaanya adalah karena Kota Tomohan ini dikelilingi oleh tiga gunung berapi yang masih akif seperti Lokon, Mahawu, dan Masarang yang menjadikan daerah ini sebagai daerah yang subur dan berlulu hawa dingin.Pasar Tomohon adalah sebuah pasar tradisional terbesar di Minahasa. Di pasar ini, dijual berbagai jenis daging sangat segar. Perkembangan usaha kecil dan menengah di kota ini sangat dinamis. Dimana di Kota Tomohon terdapat banyak wajib pajak yang melakukan pekerjaan bebas seperti pengusaha tani, bidan/dokter, furniture atau meubel, dan pengusaha lainnya.

Fenomena inilah yang dipandang menarik untuk diteliti terkait dengan faktor-faktor apa sajakah yang kemungkinan menyebabkan orang mau membayar pajak. Hal-hal apa sajakah yang besar pengaruhnya terhadap kemauan membayar pajak khususnya bagi wajib pajak yang melakukan pekerjaan bebas untuk lebih dapat meningkatkan penerimaan pajak khususnya di kota Tomohon.

Responden pada penelitian ini adalah Wajib Pajak orang pribadi yang melakukan pekerjaan bebas, yaitu pekerjaan yang dilakukan oleh orang pribadi yang mempunyai keahlian khusus sebagai usaha untuk memperoleh penghasilan yang tidak terkait oleh suatu hubungan kerja (UU KUP, 2007). Hal ini menyebabkan adanya kemungkinan Wajib Pajak yang melakukan pekerjaan bebas akan menghindari kewajiban untuk membayar pajak. Oleh karena itu ingin diteliti apakah kesadaran membayar pajak; pengetahuan dan pemahaman terhadap peraturan perpajakan; serta kualitas layanan mempengaruhi kemauan untuk membayar pajak Wajib Pajak orang pribadi yang melakukan pekerjaan bebas. Dengan harapan kemauan Wajib Pajak orang pribadi yang melakukan pekerjaan bebas semakin meningkat dalam memenuhi kewajiban membayar pajak.

Penelitian ini bertujuan menganalisis pengaruh kesadaran membayar pajak, pengetahuan perpajakan, pemahaman peraturan perpajakan,kualitas layanan terhadap kemauan membayar pajak di Kantor Pelayanan Penyuluhan dan Konsultasi Perpajakan (KP2KP) Tomohon. Dengan judul penelitian 
adalah "Pengaruh Kesadaran Membayar Pajak, Pengetahuan dan Pemahaman Peraturan Perpajakan,dan Kualitas Layanan Terhadap Kemauan Membayar Pajak Wajib Pajak Orang Pribadi Di Kota Tomohon".

\subsection{Rumusan Masalah}

Berdasarkan uraian latar belakang, maka permasalahan pada penelitian ini adalah :

1. Apakah kesadaran membayar pajak berpengaruh terhadap kemauan membayar pajak wajib pajak orang pribadi di kota Tomohon?

2. Apakah pengetahuan dan pemahaman peraturan perpajakan berpengaruh terhadap kemauan membayar pajak wajib pajak orang pribadi di kota Tomohon?

3. Apakah kualitas layanan berpengaruh terhadap kemauan membayar pajak wajib pajak orang pribadi di kota Tomohon?

\subsection{Tujuan Penelitian}

Adapun tujuan di lakukannya penelitian ini adalah :

1. Untuk mengetahui pengaruh kesadaran membayar pajak terhadap kemauan membayar pajak wajib pajak orang pribadi di kota Tomohon.

2. Untuk mengetahui pengaruh pengetahuan dan pemahaman peraturan perpajakan terhadap kemauan membayar pajak wajib pajak orang pribadi di kota Tomohon.

3. Untuk mengetahui pengaruh kualitas layanan terhadap kemauan membayar pajak wajib pajak orang pribadi di kota Tomohon.

\subsection{Manfaat Penelitian}

Adapun manfaat yang diharapkan dari penelitian ini adalah:

1. Melalui penelitian ini diharapkan dapat memberikan manfaat sebagai informasi bagi rekan-rekan mahasiswa Program Magister Akuntansi dan pembaca pada umumnya dalam aplikasi teori dan pengembangan ilmu pengetahuan yang telah dipelajari di bangku kuliah.

2. Dengan adanya penelitian ini diharapkan bisa menjadi bahan informasi pelengkap atau masukan sekaligus pertimbangan bagi pihak-pihak yang berwenang yang berhubungan dengan penelitian ini untuk meningkatkan kemauan wajib pajak dalam membayar pajak sehingga dapat mengoptimalkan penerimaan pajak negara.

3. Sebagai tambahan informasi dan masukan untuk membantu memberikan gambaran yang lebih jelas bagi para orang yang ingin melakukan penelitian mengenai faktor-faktor yang mempengaruhi kemauan membayar pajak Wajib Pajak Orang Pribadi.

\section{TINJAUAN PUSTAKA}

\subsection{Landasan Teoritis}

\subsubsection{Akuntansi Pajak}

Akuntansi pajak adalah akuntansi yang diterapkan dengan tujuan untuk menetapkan besarnya pajak terutang. Fungsi akuntansi pajak adalah mengolah data kuantitatif yang akan digunakan untuk menyajikan laporan keuangan yang memuat perhitungan perpajakan (Waluyo,2012).

Akuntansi untuk dinilai dari sifat pelaporannya, kemudian dibagi menjadi dua yaitu Akuntansi Komersial dan Akuntansi Fiskal. Akuntansi Komersial sifatnya memberi informasi kepada pihak internal perusahaan / manajemen, serta pihak eksternal perusahaan (diluar Dirjen Pajak) untuk menyediakan informasi dalam fungsi manajemen yang dihasilkan oleh akuntansi keuangan.

Akuntansi Fiskal merupakan jenis akuntansi yang berbasis informasi akuntansi yang disusun berdasarkan pada Undang-Undang dan Peraturan Perpajakan yang berlaku dan khusus digunakan untuk keperluan penghitungan Pajak Penghasilan (PPh Badan) perusahaan (UD, CV, PT dan BUT). 
Akuntansi Pajak mambahas transaksi penting badan dan berbagai Peraturan Perpajakan terkait serta pengaruhnya terhadap laporan keuangan yang khususnya menentukan besarnya laba perusahaan. Misal, penjualan \& pembelian, sewa, merger, pengalihan hak milik, dan lain-lain. Akuntansi pajak berperan dan diterapkan dalam perusahaan perseroan (PT) dan lebih berkepentingan dengan berbagai alternatif tindakan yang dapat meminimumkan nilai pajak terhutang sepanjang diperkenankan oleh Undang Undang / Peraturan Perpajakan.

\subsubsection{Kemauan Membayar Pajak}

Kepatuhan adalah motivasi seseorang, kelompok atau organisasi untuk berbuat atau tidak berbuat sesuai dengan aturan yang telah ditetapkan. Kepatuhan wajib pajak (Santoso, 2008) adalah wajib pajak mempunyai kesediaan untuk memenuhi kewajiban perpajakannya sesuai dengan peraturan yang berlaku tanpa perlu diadakannya pemeriksaan, investigasi seksama, peringatan ataupun ancaman dan penerapan sanksi baik hukum maupun administrasi.

Sesuai pasal 17 C KUP Jis KMK Nomor 544/KMK.04/2000 Direktorat Jenderal Pajak tealah mengeluarkan kriteria Wajib Pajak Patuh. Wajib Pajak Patuh adalah Wajib Pajak yang ditetapkan oleh Direktorat Jenderal Pajak sebagai Wajib Pajak yang memenuhi kriteria tertentu yang dapat diberikan pengembalian pendahuluan atas kelebihan pembayaran pajak. Kriteria Wajib Pajak Patuh tersebut antara lain sebagai berikut:

a. Tepat waktu dalam menyampaikan Surat Pemberitahuan Pajak baik Pajak Tahunan maupun Pajak Masa.

b. Tidak mempunyai tunggakan pajak untuk semua jenis pajak, kecuali telah memperoleh izin untuk mengangsur atau menunda pembayaran pajak. Mengacu pada ketentuan yang mengatur tentang angsuran dan penundaan pembayaran pajak, tidak semua jenis pajak yang terutang dapat diangsur. Pajak yang dapat diangsur pembayarannya adalah: pajak yang masih harus diabayar dalam Surat Tagihan Pajak, Surat Ketetapan Pajak Kurang Bayar, Surat Ketetapan Pajak Kurang Bayar Tambahan, Surat Keputusan Pembetulan, Surat Keputusan Keberatan, dan Putusan Banding yang menyebabkan jumlah pajak yang harus dibayar tambah. Tidak termasuk tunggakan pajak sehubungan dengan SPT yang diterbitkan untuk 2 (dua) masa pajak berakhir.

c. Tidak pernah dijatuhi hukuman karena melakukan tindakan pidana dibidang perpajakan dalam jangka waktu 10 tahun terakhir yang mengakibatkan kerugian Negara.

d. Apabila dilakukan pemeriksaan pajak, koreksi fiskal yang dilakukan oleh pemeriksa pajak untuk setiap jenis pajak yang terutang tidak lebih dari 10\% (sepuluh persen) dilihat dari penghasilan bruto (PKP).

Kepatuhan sebagai fondasi self assessment dapat dicapai apabila elemen-elemen kunci telah diterapkan secara efektif. Elemen-elemen kunci (Ismawan,2001:83) tersebut adalah sebagai berikut:

a. Program pelayanan yang baik kepada wajib pajak

b. Prosedur yang sederhana dan memudahkan wajib pajak

c. Program pemantauan kepatuhan dan verifikasi yang efektif

d. Pemantapan law enforcement secara tegas dan adil

Jadi kesimpulan pengertian wajib pajak patuh bisa disimpulkan menjadi dua, yaitu:

a. Kepatuhan formal adalah suatu keadaan di mana wajib pajak memenuhi kewajiban secara formal sesuai dengan ketentuan dalam Undang-Undang Perpajakan.

b. Kepatuhan material adalah suatu keadaan di mana wajib pajak memenuhi semua ketentuan material perpajakan, yakni sesuai dengan isi dan jiwa Undang-Undang perpajakan. Kepatuhan material dapat juga meliputi kepatuhan formal.

Konsep kemauan membayar pajak dikembangkan melalui dua subkonsep yaitu, konsep kemauan membayar dan konsep pajak. Pertama, konsep kemauan membayar. Kemauan membayar merupakan suatu nilai dimana seseorang rela untuk membayar,mengorbankan atau menukarkan sesuatu untuk memperoleh barang atau jasa (Widaningrum, 2007). Kedua, konsep pajak. Menurut 
Taylor (Waluyo, 2007) pajak adalah prestasi yang dipaksakan sepihak oleh negara dan terutang kepada pengusaha (menurut norma-norma yang ditetapkan secara umum), tanpa adanya kontraprestasi, dan semata-mata digunakan untuk menutup pengeluaran-pengeluaran umum.

Berdasarkan definisi dari dua subkonsep di atas, maka dapat dikembangkan suatu definisi untuk kemauan membayar pajak (willingness to pay tax). Kemauan membayar pajak dapat diartikan sebagai suatu nilai yang rela dikontribusikan oleh seseorang (yang ditetapkan dengan peraturan) yang digunakan untuk membiayai pengeluaran umum negara dengan tidak mendapat jasa timbal (kontraprestasi) secara langsung.

Kemauan membayar pajak dipengaruhi oleh beberapa faktor yaitu kondisi sistem administrasi perpajakan suatu negara, pelayanan pada wajib pajak, penegakan hukum perpajakan, dan tarif pajak (Devano dan Rahayu 2006).

\subsubsection{Kesadaran Membayar Pajak}

Kemajuan dan perkembangan negara ini tak lepas dari kesadaran warganya dalam membayar pajak. Kesadaran masyarakat dalam membayar pajak sangat erat hubungannya dengan kesadaran bernegara. Menurut Siahaan (2010:106) apabila kesadaran bernegara kurang maka masyarakat kurang dapat mengenal dan menikmati pentingnya berbangsa dan bertanah air, berbahasa nasional, menikmati keamanan dan ketertiban, memiliki dan menikmati kebudayaan nasional dan pada akhirnya apabila kesadaran bernegara kurang maka rasa memiliki dan menikmati manfaat pengeluaran pemerintah juga kurang sehingga kesadaran membayar pajak juga berkurang.

Kesadaran membayar pajak dapat diartikan sebagai suatu bentuk sikap moral yang memberikan sebuah kontribusi kepada negara untuk menunjang pembangunan negara dan berusaha untuk mentaati semua peraturan yang telah ditetapkan oleh negara serta dapat dipaksakan kepada Wajib Pajak. Meningkatnya pengetahuan perpajakan masyarakat melalui pendidikan perpajakan baik formal maupun non formal akan berdampak positif terhadap kesadaran wajib pajak untuk membayar pajak. Karakteristik wajib pajak yang dicerminkan oleh kondisi budaya, sosial, dan ekonomi akan dominan membentuk perilaku wajib pajak yang tergambar dalam tingkat kesadaran mereka dalam membayar pajak.

\subsubsection{Pengetahuan dan Pemahaman Peraturan Perpajakan}

Pengetahuan pajak adalah proses pengubahan sikap dan tata laku seorang wajib pajak atau kelompok wajib pajak dalam usaha mendewasakan manusia melalui upaya pengajaran dan pelatihan. Pengetahuan akan peraturan perpajakan masyarakat melalui pendidikan formal maupun non formal akan berdampak positif terhadap kesadaran wajib pajak untuk membayar pajak seperti penyuluhan atau sosialisasi pajak yang dilakukan KP2KP Tomohon di kantor-kantor,sekolah-sekolah ataupun di desa-desa sekitar.

Pemahaman wajib pajak terhadap peraturan perpajakan adalah cara wajib pajak dalam memahami peraturan perpajakan yang telah ada. Wajib pajak yang tidak memahami peraturan perpajakan secara jelas cenderung akan menjadi wajib pajak yang tidak taat. Jelas bahwa semakin paham wajib pajak terhadap peraturan perpajakan, maka semakin paham pula wajib pajak terhadap sanksi yang akan diterima bila melalaikan kewajiban perpajakan mereka. Dimana wajib pajak yang benar-benar paham, mereka akan mengetahui sanksi adminstrasi dan sanksi pidana sehubungan dengan SPT dan NPWP.

\subsubsection{Kualitas Layanan terhadap Wajib Pajak}

Kualitas layanan adalah pelayanan yang dapat memberikan kepuasan kepada pelanggan dan tetap dalam batas memenuhi standar pelayanan yang dapat dipertangggungjawabkan serta harus dilakukan secara terus-menerus. Secara sederhana definisi kualitas adalah suatu kondisi dinamis yang berhubungan dengan produk, jasa manusia, proses, dan lingkungan yang memenuhi atau melebihi harapan pihak yang menginginkannya. Pelayanan perpajakan dibentuk oleh dimensi kualitas sumber 
daya manusia (SDM), ketentuan perpajakan dan sistem informasi perpajakan. Standar kualitas pelayanan prima kepada masyarakat wajib pajak akan terpenuhi bilamana SDM melakukan tugasnya secara profesional, disiplin, dan transparan. Dalam kondisi wajib pajak merasa puas atas pelayanan yang diberikan kepadanya, maka mereka akan cenderung akan melaksanakan kewajiban membayar pajak sesuai dengan ketentuan yang berlaku. Apabila ketentuan perpajakan dibuat sederhana, mudah dipahami oleh wajib pajak, maka pelayanan perpajakan atas hak dan kewajiban mereka dapat dilaksanakan secara efektif dan efisien. Dengan demikian sistem informasi perpajakan dan kualitas SDM yang handal akan menghasilkan pelayanan perpajakan yang semakin baik.

\subsection{Penelitian Terdahulu}

Widayati dan Nurlis (2010) dalam penelitiannya yang berjudul, "Faktor-Faktor Yang Mempengaruhi Kemauan Untuk Membayar Pajak Wajib Pajak Orang Pribadi Yang Melakukan Pekerjaan Bebas (Studi Kasus Pada Kpp Pratama Gambir Tiga)”, menyimpulkan bahwa pengetahuan dan pemahaman akan peraturan perpajakan, pelayanan fiskus yang berkualitas, dan persepsi atas efektifitas sistem perpajakan berpengaruh postif terhadap kemauan membayar pajak. Berbeda dengan penelitian ini adalah peneliti sebelumnya menggunakan random sampling, sedangkan peneliti menggunakan convenience random sampling dalam metode penentuan sampel.

Pancawati Hardiningsih (2011) dalam penelitiannya yang berjudul, "Faktor- Faktor yang Mempengaruhi Kemauan Membayar Pajak", menyimpulkan bahwa kesadaran wajib pajak membayar pajak berpengaruh dan signifikan terhadap kemauan membayar pajak, sikap wajib pajak terhadap pengetahuan peraturan perpajakan, pemahaman peraturan perpajakan dan persepsi efektifitas sistem perpajakan tidak berpengaruh terhadap kemauan membayar pajak, dan untuk kualitas layanan berpengaruh positif terhadap kemauan membayar pajak. Perbedaannya dengan penelitian ini terletak pada objek penelitiannya.

\section{KERANGKA KONSEPTUAL}

\subsection{Kerangka Konseptual Penelitian}

Adapun kerangka konseptual yang dapat digambarkan untuk menjelaskan alur pemikiran dalam penelitian ini adalah sebagai berikut :

\section{Gambar 3.1 Kerangka Konseptual}

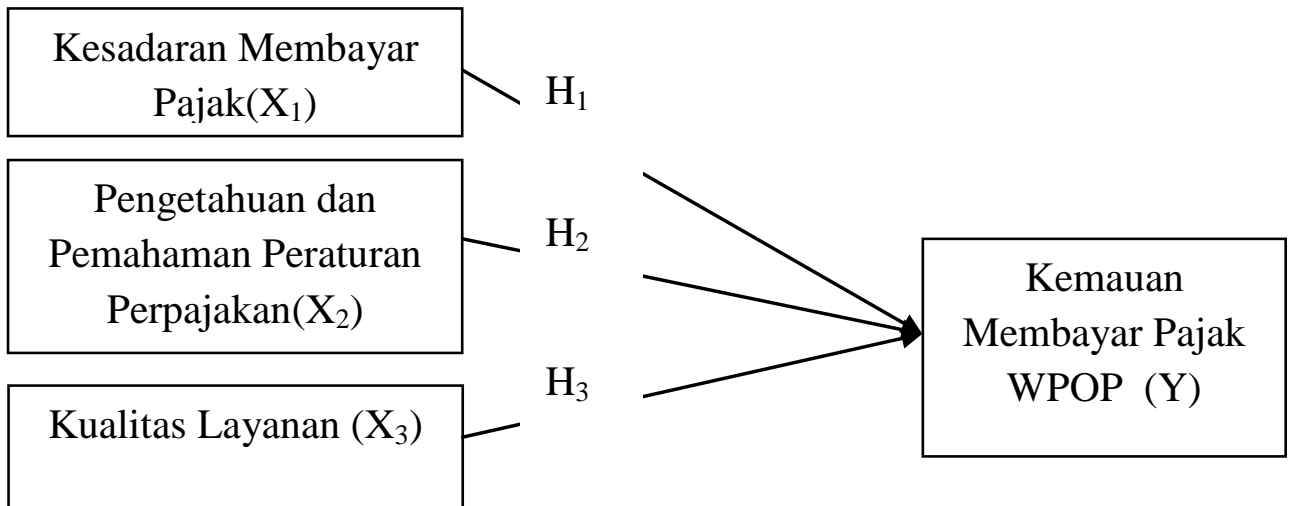

\subsection{Hipotesis}

Kesadaran merupakan unsur dalam manusia dalam memahami realitas dan bagaimana cara bertindak atau menyikapi terhadap realitas. Kesadaran yang dimiliki oleh manusia kesadaran dalam diri,akan diri sesama,masa silam,dan kemungkinan masa depannya (Widayati dan Nurlis, 2010). Kesadaran yang tinggi itu sendiri muncul tidak lain berasal dari adanya motivasi Wajib Pajak. Apabila kesadaran Wajib Pajak tinggi yang datang dari motivasi untuk membayar pajak, maka kemauan untuk membayar pajakpun akan tinggi dan pendapatan Negara dari pajak akan meningkat. Hipotesis yang dirumuskan adalah : 

Pajak Orang Pribadi di Kota Tomohon.

Pengetahuan wajib pajak tentang pajak adalah proses pengubahan sikap dan tata laku seorang atau kelompok wajib pajak dalam usaha mendewasakan manusia melalui upaya pengajaran dan pelatihan. Pengetahuan peraturan perpajakan dalam sistem perpajakan yang baru, wajib pajak diberikan kepercayaan untuk melaksanakan kegotong royongan nasional melalui sistem menghitung, memperhitungkan,membayar,melaporkan sendiri pajak yang terutang, sehingga diharapkan akan tercipta unsur keadilan dan kebenaran mengingat bahwa wajib pajak sendirilah yang sebenarnya mengetahui besarnya pajak yang terutang. Pemahaman wajib pajak terhadap peraturan perpajakan adalah cara wajib pajak dalam memahami peraturan perpajakan yang telah ada. Wajib pajak yang tidak memahami peraturan perpajakan secara jelas cenderung akan menjadi wajib pajak yang tidak taat. Jelas bahwa semakin paham wajib pajak terhadap peraturan perpajakan,maka semakin paham pula wajib pajak terhadap sanksi yang akan diterima bila melalaikan kewajiban perpajakan mereka. Setiap wajib pajak yang telah memahami peraturan sangat baik, biasanya akan melakukan aturan perpajakan yang sesuai dengan apa yang tercantum di dalam peraturan yang ada. Hipotesis yang dirumuskan adalah :

$\mathrm{H}_{2} \quad$ : Pengetahuan dan Pemahaman Peraturan Perpajakan berpengaruh terhadap Kemauan Membayar Pajak Wajib Pajak Orang Pribadi di Kota Tomohon.

Kualitas layanan adalah pelayanan yang dapat memberikan kepuasan kepada pelanggan dan tetap dalam batas memenuhi standar pelayanan yang dapat dipertangggungjawabkan serta harus dilakukan secara terus-menerus. Apabila jasa dari suatu instansi tidak memenuhi harapan pelanggan,berarti jasa pelayanan tidak berkualitas. Jika proses pelayanan tidak memenuhi harapan pelanggan, berarti mutu pelayanannya kurang. Pelayanan kepada pelanggan dikatakan bermutu apabila memenuhi atau melebihi harapan pelanggan atau semakin kecil kesenjangan antara pemenuhi janji dengan harapan pelanggan adalah semakin mendekati ukuran bermutu. Kemauan WP dalam memenuhi kewajibannya membayar pajak tergantung pada bagaimana petugas pajak memberikan mutu pelayanan yang terbaik kepada wajib pajak. Fiskus yang bertanggung jawab dan mendayagunakan SDM sangat dibutuhkan guna meningkatkan kemauan dalam membayar pajak. Para wajib pajak akan mau dalam memenuhi kewajibannya membayar pajak tergantung pada bagaimana petugas pajak tersebut memberikan pelayanan yang terbaik kepada wajib pajak. Untuk mewujudkan pelayanan yang baik, petugas harus mempunyai pengetahuan dan pengalaman dibidang perpajakan serta dalam hal perundang-undangan.Berdasarkan uraian diatas dapat disimpulkan suatu hipotesis sebagai berikut:

$\mathrm{H}_{3}$ : Kualitas Layanan berpengaruh terhadap Kemauan Membayar Pajak Wajib Pajak Orang Pribadi di Kota Tomohon.

\section{METODE PENELITIAN}

\subsection{Jenis/Rancangan Penelitian yang Digunakan}

\subsubsection{Jenis Penelitian}

Jenis Penelitian Tesis ini adalah penelitian kuantitatif. Penelitian kuantitatif merupakan penelitian yang menggunakan angka untuk menjelaskan hasil penelitiannya, dan biasanya menggunakan bantuan statistik untuk pengolahan data (Kuncoro 2003:124). Jenis data yang dipergunakan adalah data kualitatif yang dikuantitatifkan karena dalam statistik semua data harus dalam bentuk angka, maka data kualitatif umumnya dikuantitatifkan agar dapat diproses lebih lanjut. Data kualitatif sebagai data utama dalam penelitian ini yaitu berbentuk uraian melalui respon tertulis (kuesioner). 


\subsubsection{Sumber Data}

Sumber data yang dipakai dalam penelitian ini adalah data primer. Data primer dikumpulkan dimaksudkan untuk menjawab pertanyaan penelitian baik itu secara lisan atau tertulis. Terdapat dua teknik pengumpulan data primer, yakni melalui media wawancara ataupun dengan kuesioner .

Data sekunder juga dikumpulkan Sebagai penunjang dalam penelitian ini. Data sekunder dalam penelitian ini adalah data yang diperoleh dari pihak Kantor Pelayanan Penyuluhan dan Konsultasi Perpajakan (KP2KP) Tomohon yang berhubungan dengan penelitian ini. Penulis juga mengambil referensi melalui data sekunder yang didapat melalui literatur-literatur yang ada serta informasiinformasi dari internet dan lembaga penyedia data sekunder lainnya yang dapat dijadikan acuan bagi penelitian ini.

\subsection{Populasi, Sampel, Besar Sampel, dan Teknik Pengambilan Sampel}

Populasi dalam penelitian ini adalah Wajib Pajak Orang Pribadi yang Melakukan Pekerjaan Bebas yang terdaftar di KP2KP Tomohon per Desember 2012 dengan jumlah 21.480. Dengan jumlah Populasi adalah 21.480 dan presisi yang ditetapkan adalah $10 \%$,jika dimasukkan dalam rumus penentuan sampel maka diperoleh Jumlah Sampel sebagai berikut :

$\mathrm{n}=21.480 /(21.480 \times 0.10 \times 0.10+1)$

\section{$\mathrm{n}=\mathbf{9 9 . 9 9 5}=\mathbf{1 0 0}$}

Dalam menentukan sampel penelitian menggunakan teknik pengambilan sampel yaitu teknik Convinience Random Sampling. Teknik ini memilih sampel dari mengambil sampel yang sesuai dengan ketentuan atau persyaratan sampel dari populasi tertentu yang paling mudah dijangkau atau didapatkan, misalnya yang terdekat dengan tempat peneliti berdomisili( Prasetyo,2011).

Setelah mendapatkan objek penelitian tersebut, maka dibagikan angket pada 77 Wajib Pajak Orang Pribadi tersebut, sehingga dalam penelitian ini memenuhi syarat ukuran sampel dalam statistika.

\subsection{Klasifikasi Variabel dan Definisi Operasional Variabel}

Adapun variabel-variabel yang digunakan dalam penelitian ini diambil dari penelitian sebelumnya oleh Handayani,2011 yaitu sebagai berikut :

1. Kesadaran Membayar Pajak adalah keadaan mengetahui atau mengerti, sedangkan kesadaran wajib pajak dalam kewajiban perpajakannya merupakan hal penting dalam penarikan pajak.

2. Pengetahuan Peraturan Perpajakan adalah proses pengubahan sikap dan tata laku seorang wajib pajak atau kelompok wajib pajak dalam usaha mendewasakan manusia melalui upaya pengajaran dan pelatihan. Pemahaman Peraturan Perpajakan adalah cara wajib pajak dalam memahami peraturan perpajakan yang telah ada. Wajib pajak yang tidak paham akan peraturan perpajakan maka cenderung menjadi wajib pajak yang tidak taat.

3. Pelayanan adalah cara melayani (membantu mengurus atau menyiapkan segala keperluan yang dibutuhkan seseorang). Secara sederhana definisi kualitas adalah suatu kondisi dinamis yang berhubungan dengan produk,jasa manusia, proses, dan lingkungan yang memenuhi atau melebihi harapan pihak yang menginginkannya.

4. Kemauan membayar pajak sebagai suatu nilai yang rela dikontribusikan oleh seseorang (yang ditetapkan dengan peraturan) yang digunakan untuk membiayai pengeluaran umum Negara dengan tidak mendapat jasa timbal (kontraprestasi) secara langsung.

Semua Variabel ini diukur dengan menggunakan skala likert (skor jawaban) 1 (sangat tidak setuju), 2 (tidak setuju), 3 (netral), 4 (setuju), 5 (sangat setuju).

\subsection{Instrumen Penelitian}

Adapun sebelum menggunakan analisis ini, dilakukan terlebih dahulu uji validitas dan reliabilitas dengan bantuan software SPSS 19. Uji validitas bertujuan untuk mengukur valid tidaknya suatu item pernyataan, sedangkan uji reliabilitas bertujuan untuk mengukur konsisten tidaknya sebuah jawaban seseorang terhadap item-item pernyataan di dalam sebuah angket/kuesioner (Sarjono \& Julianita, 2011 : 35). Dalam Penelitian ini kuesioner yang dipakai diambil dari peneliti terdahulu. 
Uji asumsi klasik juga dilakukan dengan bantuan software SPSS 19 yang meliputi uji normalitas, uji multikolinearitas, uji autokorelasi dan uji heteroskedastisitas. Setelah dilakukan pengujian asumsi klasik maka dilakukan pengujian regresi linear berganda dengan persamaan sebagai berikut.

Keterangan :

$$
\mathbf{Y}=\alpha+\boldsymbol{\beta}_{1} \mathbf{X}_{1}+\boldsymbol{\beta}_{2} \mathbf{X}_{2}+\boldsymbol{\beta}_{3} \mathbf{X}_{3}+\mathbf{e}
$$

$\mathrm{Y} \quad=$ kemauan membayar pajak wajib pajak orang pribadi

$\alpha \quad=$ Konstanta / Intercept

$\beta_{1}-\beta_{3}, \quad=$ Koefisien Regresi

$\mathrm{X}_{1} \quad=$ Kesadaran Membayar Pajak

$\mathrm{X}_{2} \quad=$ Pengetahuan dan Pemahaman Peraturan Perpajakan

$\mathrm{X}_{3} \quad=$ Kualitas layanan

e $\quad$ error

\section{HASIL ANALISIS DAN PEMBAHASAN}

\subsection{Hasil Analisis}

5.1.1. Uji Validitas

Pengujian validitas diperoleh dengan menguji tiap kuisioner yang ada dengan nilai korelasi minimal 0,30. jika butir instrument nilainya dibawah 0,30 maka pertanyaan tersebut tidak valid dan jika nilainya diatas 0,30 maka pertanyaan tersebut valid (Azwar ,2006:158)

Tabel 5.1

Hasil Pengujian Validitas $\left(\mathbf{X}_{1}\right)$ Kesadaran Membayar Pajak

\begin{tabular}{|c|c|c|}
\hline Pertanyaan & Pearson Correlation & Keterangan \\
\hline P1 & 0.868 & Valid \\
\hline P2 & 0.897 & Valid \\
\hline P3 & 0.899 & Valid \\
\hline P4 & 0.846 & Valid \\
\hline P5 & 0.846 & Valid \\
\hline
\end{tabular}

Sumber : Output Pengolahan Data SPSS, 2013

Tabel 5.2

Hasil Pengujian Validitas $\left(\mathbf{X}_{2}\right)$ Pengetahuan dan Pemahaman Peraturan Perpajakan

\begin{tabular}{|c|c|c|}
\hline Pertanyaan & Pearson Correlation & Keterangan \\
\hline P1 & 0.788 & Valid \\
\hline P2 & 0.721 & Valid \\
\hline P3 & 0.836 & Valid \\
\hline P4 & 0.799 & Valid \\
\hline P5 & 0.739 & Valid \\
\hline
\end{tabular}

Sumber : Output Pengolahan Data SPSS, 2013

Tabel 5.3

Hasil Pengujian Validitas $\left(\mathbf{X}_{3}\right)$ Kualitas Layanan

\begin{tabular}{|c|c|c|}
\hline Pertanyaan & Pearson Correlation & Keterangan \\
\hline P1 & 0.815 & Valid \\
\hline P2 & 0.660 & Valid \\
\hline P3 & 0.778 & Valid \\
\hline P4 & 0.863 & Valid \\
\hline P5 & 0.689 & Valid \\
\hline
\end{tabular}

Sumber : Output Pengolahan Data SPSS, 2013 
Tabel 5.4

Hasil Pengujian Validitas (Y) Kemauan Membayar Pajak Wajib Pajak Orang Pribadi

\begin{tabular}{|c|c|c|}
\hline Pertanyaan & Pearson Correlation & Keterangan \\
\hline P1 & 0.798 & Valid \\
\hline P2 & 0.630 & Valid \\
\hline P3 & 0.788 & Valid \\
\hline P4 & 0.864 & Valid \\
\hline P5 & 0.683 & Valid \\
\hline
\end{tabular}

Sumber : Output Pengolahan Data SPSS, 2013

Hasil uji validitas menunjukkan nilai korelasi masing - masing pertanyaan adalah diatas 0.3 , hal ini menjelaskan bahwa masing - masing pertanyaan adalah valid dan dapat digunakan dalam kuesioner.

\subsubsection{Uji Reliabilitas}

Suatu instrument dapat dikatakan reliabel jika nilai alpha cronbach $>0,6$, dan sebaliknya dikatakan tidak reliabel jika alpha cronbach < 0,6 (Ghozali,2005).

Tabel 5.5 Hasil Uji Reliabilitas

\begin{tabular}{|c|c|c|c|}
\hline Variabel & Croanbach's Alpha & Standar & Keterangan \\
\hline X1 & 0.925 & 0.6 & Reliabel \\
\hline X2 & 0.836 & 0.6 & Reliabel \\
\hline X3 & 0.820 & 0.6 & Reliabel \\
\hline Y & 0.809 & 0.6 & Reliabel \\
\hline
\end{tabular}

Sumber : Output Pengolahan Data SPSS, 2013

Hasil uji reliabilitas menunjukan bahwa nilai cronbach alpha lebih dari 0.6, hal ini menunjukan bahwa pertanyaan - pertanyaan yang digunakan sebagai alat ukur dalam penelitian ini adalah reliabel.

\subsubsection{Uji Asumsi Klasik}

\section{Uji Normalitas}

Pengujian normalitas ini bertujuan untuk mengetahui apakah data yang digunakan telah terdistribusi secara normal. Hasil uji normalitas dengan grafik yang diolah SPSS, normal probability ditunjukan sebagai berikut :

\section{Gambar 5.1 Hasil Uji Normalitas}

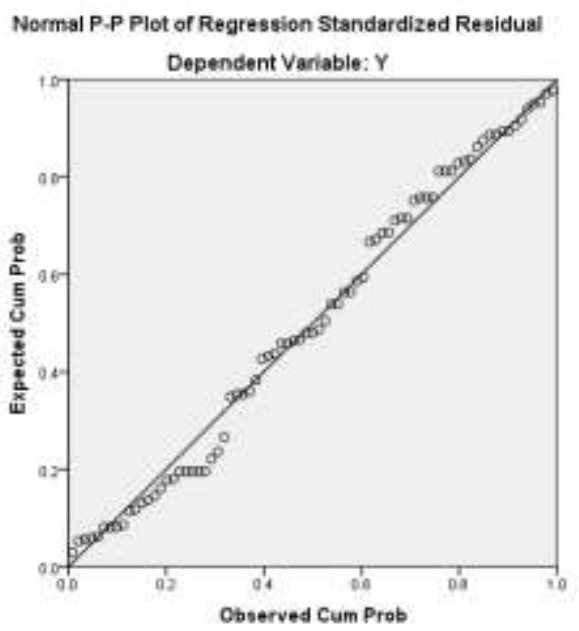

Sumber : Data olahan SPSS, 2014 
Dari gambar diatas dapat dilihat bahwa data menyebar di sekitar garis diagonal dan mengikuti arah garis diagonal, maka data terdistribusi dengan normal sehingga dapat dikatakan model regresi telah memenuhi asumsi normalitas.

\section{Uji Heteroskedastisitas}

Heteroskedastisitas adalah keadaan dimana terjadinya ketidaksamaan varian dari residual pada model regresi. Model regresi yang baik mensyaratkan tidak adanya masalah heteroskedastisitas. Untuk mendeteksi ada tidaknya heteroskedastisitas adalah dengan melihat pola titik-titik pada scatterplots regresi.Jika titik-titik menyebar dengan pola tidak jelas di atas dan di bawah angka 0 pada sumbu Y maka tidak terjadi masalah hateroskedastisitas.Scatterplots dapat dilihat pada output regresi dan disajikan sebagai berikut:

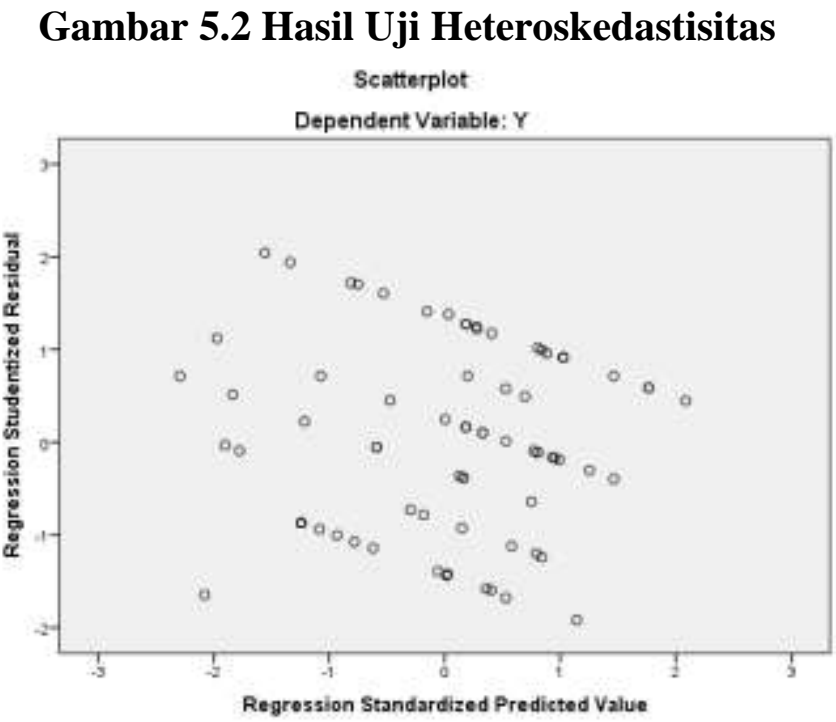

Sumber : Data olahan SPSS, 2014

Dari gambar 5.2 terlihat bahwa dalam persamaan regresi ini tidak terdapat heteroskedastisitas.Hal ini terlihat dari penyebaran titik-titik yang tidak memiliki pola yang jelas,serta titik-titik tersebut menyebar di atas dan dibawah angka 0 pada sumbu Y,sehingga dalam persamaan ini tidak terjadi gejala heteroskedisitas.

\section{Uji Autokorelasi}

Uji ini bertujuan untuk menguji apakah dalam suatu model regresi linier terdapat korelasi antara kesalahan pengganggu pada periode $t$ dengan kesalahan ada periode $\mathrm{t}-1$ (sebelumnya). Menurut Ghozali (2005), model regresi yang baik adalah model regresi yang bebas dari autokorelasi.

Tabel 5.6 Hasil Uji Autokorelasi

\begin{tabular}{|l|r|r|r|r|r|}
\hline Model & \multicolumn{1}{|c|}{$\mathrm{R}$} & $\mathrm{R}$ Square & $\begin{array}{c}\text { Adjusted } \mathrm{R} \\
\text { Square }\end{array}$ & $\begin{array}{c}\text { Std. Error of the } \\
\text { Estimate }\end{array}$ & Durbin-Watson \\
\hline 1 & $.401^{\mathrm{a}}$ & .161 & .126 & 1.84140 & 1.705 \\
\hline
\end{tabular}

a. Predictors: (Constant), KUALITAS, KESADARAN, PENGETAHUAN,

b. Dependent Variable: KEMAUAN MEMBAYAR

Sumber : Data olahan SPSS, 2014

Hasil uji autokorelasi diatas menunjukan nilai statistik Durbin Watson (DW) sebesar 1.705 maka dapat dikatakan penelitian ini bebas dari problem autokorelasi atau kesalahan pengganggu sebab DW terletak diantara -2 sampai +2 yang berarti tidak ada autokorelasi. 


\section{Uji Multikolinearitas}

Uji multikolinearitas bertujuan untuk menguji apakah model regresi ditemukan adanya korelasi antara variabel bebas (independen).Model regresi yang baik seharusnya tidak terjadi korelasi diantara variabel independen (Ghozali, 2005).Pengujian ini dilakukan dengan menganalisis matriks korelasi variabel-variabel bebas yang akan digunakan dalam persamaan regresi. Jika antar variabel bebas ada korelasi yang tinggi (umumnya di atas 0,90), maka hal ini merupakan indikasi adanya multikolinearitas.

Untuk mendeteksi ada tidaknya multikolinearitas dengan melihat nilai tolerance dan VIF.Semakin kecil nilai Tolerance dan semakin besar nilai VIF maka senakin mendekati terjadinya masalah multikolinearitas. Nilai cut off yang umum dipakai untuk menunjukan adanya multikolinearitas adalah nilai tolerance $>0,10$ atau nilai $\mathrm{VIF}<10$.

Tabel 5.7 Hasil Uji Multikolinearitas

\begin{tabular}{|c|c|c|c|}
\hline \multirow{2}{*}{\multicolumn{2}{|c|}{ Model }} & \multicolumn{2}{|c|}{ Collinearity Statistics } \\
\hline & & Tolerance & \\
\hline \multirow{4}{*}{1} & (Constant) & & \\
\hline & $\mathrm{X} 1$ & & 1.003 \\
\hline & $\mathrm{X} 2$ & & 1.044 \\
\hline & X3 & & 1.042 \\
\hline
\end{tabular}

Sumber : Data olahan SPSS, 2014

Dari tabel 5.7 terlihat bahwa tidak ada variabel bebas yang memiliki nilai tolerance kurang dari 0,10. Hasil uji VIF juga menunjukan hal yang sama yaitu tidak ada satupun variabel independen yang memiliki VIF lebih dari 10. Sehingga dapat disimpulkan bahwa tidak terjadi multikolinearitas antar variabel bebas dalam persamaan regresi.

\subsubsection{Pengujian Hipotesis}

\section{Uji Parsial (Uji-t)}

Untuk mengetahui apakah masing - masing variabel independen berpengaruh terhadap variabel dependen, dilakukan uji statistik t sebagai berikut :

\section{Tabel 5.8 Hasil Uji Statistik t}

Coefficients $^{\mathrm{a}}$

\begin{tabular}{|c|c|c|c|c|c|c|}
\hline \multirow[t]{2}{*}{ Mode } & & \multicolumn{2}{|c|}{ Unstandardized Coefficients } & Standardized & \multirow[t]{2}{*}{$\mathrm{t}$} & \multirow[t]{2}{*}{ Sig. } \\
\hline & & $B$ & Std. Error & Beta & & \\
\hline \multirow{4}{*}{1} & (Constant) & 9.830 & 3.496 & & 2.811 & .006 \\
\hline & $\mathrm{X} 1$ & .246 & .118 & .224 & 2.085 & .041 \\
\hline & $\mathrm{X} 2$ & .202 & .092 & 241 & 2.202 & .031 \\
\hline & X3 & .127 & .082 & 169 & 1.548 & .126 \\
\hline
\end{tabular}

Sumber: Data olahan SPSS, 2014

Berdasarkan tabel uji t diatas dapat dijelaskan pengaruh masing - masing variabel $\mathrm{X}$ terhadap $\mathrm{Y}$ sebagai berikut :

1. Kesadaran Membayar Pajak $\left(\mathrm{X}_{1}\right)$ mempunyai nilai signifikasi 0.041 yang berarti nilai ini lebih kecil dari 0.05, dengan $\mathrm{t}$ hitung sebesar 2.085 dan $\mathrm{t}$ tabel $1.664 \mathrm{t}$ hitung $>\mathrm{t}$ tabel, berdasarkan hal tersebut disimpulkan bahwa secara parsial kesadaran membayar pajak berpengaruh terhadap kemauan membayar pajak wajib pajak orang pribadi di Kota Tomohon karena nilai signifikasi yang lebih kecil dari 0.05 dan $\mathrm{t}$ hitung $>\mathrm{t}$ tabel.

2. Pengetahuan dan Pemahaman Peraturan Perpajakan $\left(X_{2}\right)$ mempunyai nilai signifkasi 0,031 yang berarti nilai ini lebih kecil dari 0.05 dengan $t$ hitung sebesar 2.202 dan $t$ tabel $1.664, \mathrm{t}$ hitung > t tabel. berdasarkan hal tersebut disimpulkan bahwa secara parsial variabel pengetahuan dan pemahaman peraturan perpajakan berpengaruh terhadap kemauan membayar 
pajak wajib pajak orang pribadi di Kota Tomohon karena nilai signifikasi yang lebih kecil dari 0.05 dan $t$ hitung $>\mathrm{t}$ tabel.

3. Kualitas Layanan $\left(\mathrm{X}_{3}\right)$ mempunyai nilai signifikasi 0,126 yang berarti nilai ini lebih besar dari 0.05 dengan t hitung sebesar 1.548 dan t tabel 1.664, $\mathrm{t}$ hitung $<\mathrm{t}$ tabel.Berdasarkan hal tersebut disimpulkan bahwa secara parsial variabel kualitas layanan berpengaruh tetapi tidak signifikan terhadap kemauan membayar pajak wajib pajak orang pribadi di Kota Tomohon karena nilai signifikasi yang lebih besar dari 0.05 dan $t$ hitung $<\mathrm{t}$ tabel.

\section{Uji Signifikan Simultan (Uji-F)}

Dalam penelitian ini untuk mengetahui apakah variabel kesadaran membayar pajak, pengetahuan dan pemahaman peraturan perpajakan dan kualitas layanan berpengaruh terhadap kemauan membayar pajak wajib pajak orang pribadi secara bersama- sama,di gunakan uji statistik F. Hasil uji statistik F dengan program SPSS dapat dilihat dalam tabel berikut :

Tabel 5.9 Hasil Statistik Uji F

ANOVA $^{a}$

\begin{tabular}{|rl|r|r|r|r|r|}
\hline Model & & Sum of Squares & $\mathrm{df}$ & Mean Square & $\mathrm{F}$ & Sig. \\
\hline \multirow{4}{*}{1} & Regression & 47.463 & 3 & 15.821 & 4.666 & $.005^{\mathrm{D}}$ \\
& Residual & 247.524 & 73 & 3.391 & & \\
& Total & 294.987 & 76 & & & \\
\hline
\end{tabular}

a. Dependent Variable: $Y$

b. Predictors: (Constant), X3, X1, X2

Sumber : Data olahan SPSS, 2014

Berdasarkan tabel 5.10 diperoleh F hitung sebesar 4.666 dengan tingkat signifikansi 0.005 jauh lebih kecil dari 0.05 oleh karena itu maka model regresi bisa dipakai untuk memprediksi variabel kemauan membayar pajak wajib pajak orang pribadi.

\subsection{Pembahasan}

Berdasarkan hasil pengujian regresi berganda yang telah dilakukan diketahui persamaan regresi berganda yang diperoleh dengan menggunakan metode kuadrat terkecil adalah $Y=9.830+\mathbf{0 . 2 4 6} X_{1}$ $\mathbf{+ 0 . 2 0 2} \mathrm{X}_{2}+\mathbf{0 . 1 2 7} \mathrm{X}_{3}+\mathbf{e}$ dimana hubungan variabel dependen dengan variabel independen cukup kuat yaitu sebesar $40 \%$, sedangkan nilai R Square atau koefisien determinasi adalah 0.161 , nilai ini mengindikasikan bahwa $16.1 \%$ variasi atau perubahan dalam variabel dependen dapat dijelaskan oleh variasi atau perubahan variabel independen, dan sisanya yaitu $83.9 \%$ dipengaruhi oleh faktor lain yang tidak dimasukkan kedalam penelitian ini. Sebagaimana diketahui bahwa dalam sistem perpajakan yang baru, wajib pajak diberikan kepercayaan untuk melaksanakan kegotongroyongan nasional melalui sistem menghitung, memperhitungkan, membayar, melaporkan sendiri pajak yang terutang. Besarnya pajak dihitung sendiri oleh wajib pajak, kemudian membayar pajak yang terutang berdasarkan ketentuan peraturan perundang-undangan perpajakan yang berlaku. Lerche (2000) juga mengemukakan bahwa kesadaran perpajakan seringkali menjadi kendala dalam masalah pengumpulan pajak dari masyarakat. Kesadaran wajib pajak atas perpajakan amatlah diperlukan guna meningkatkan kepatuhan wajib pajak.

Berdasarkan hasil uji $\mathrm{t}$ dan uji f yang telah dilakukan diketahui bahwa secara parsial variabel kesadaran membayar pajak berpengaruh secara signifikan terhadap variabel kemauan membayar pajak wajib pajak orang pribadi,sama halnya dengan variabel pengetahuan dan pemahaman peraturan perpajakan dan kualitas layanan berpengaruh terhadap variabel kemauan membayar pajak wajib pajak orang pribadi.Kemudian secara simultan ketiga variabel secara bersama-sama berpengaruh terhadap variabel kemauan membayar pajak wajib pajak orang pribadi. Penjelasan masing- masing variabel dan pengaruhnya adalah sebagai berikut : 


\subsubsection{Pengaruh Kesadaran Membayar Pajak terhadap Kemauan Membayar Pajak Wajib Pajak Orang Pribadi}

Berdasarkan hasil uji t yang dilakukan untuk melihat pengaruh kesadaran membayar pajak terhadap variabel kemauan membayar pajak wajib pajak orang pribadi diketahui bahwa kesadaran membayar pajak $\left(\mathrm{X}_{1}\right)$ mempunyai nilai signifikasi 0.041 yang berarti nilai ini lebih kecil dari 0.05 , dengan $\mathrm{t}$ hitung sebesar 2.085 dan $\mathrm{t}$ tabel $1.664 \mathrm{t}$ hitung $>\mathrm{t}$ tabel, berdasarkan hal tersebut disimpulkan bahwa secara parsial kesadaran membayar pajak berpengaruh terhadap kemauan membayar pajak wajib pajak orang pribadi di Kota Tomohon karena nilai signifikasi yang lebih kecil dari 0.05 dan $t$ hitung $>\mathrm{t}$ tabel.

Hasil penelitian untuk variabel ini sesuai dengan penelitian yang dilakukan oleh Widayati dan Nurlis, (2010). Yang menyatakn bahwa kesadaran merupakan unsur dalam manusia dalam memahami realitas dan bagaimana cara bertindak atau menyikapi terhadap realitas. Kesadaran yang dimiliki oleh manusia kesadaran dalam diri, akan diri sesama, masa silam, dan kemungkinan masa depannya. Kesadaran yang tinggi itu sendiri muncul tidak lain berasal dari adanya motivasi Wajib Pajak. Apabila kesadaran Wajib Pajak tinggi yang datang dari motivasi untuk membayar pajak, maka kemauan untuk membayar pajakpun akan tinggi dan pendapatan Negara dari pajak akan meningkat.

\subsubsection{Pengaruh Pengetahuan dan Pemahaman Peraturan Perpajakan terhadap Kemauan Membayar Pajak Wajib Pajak Orang Pribadi}

Berdasarkan hasil uji t yang dilakukan untuk melihat pengaruh pengetahuan dan pemahaman peraturan perpajakan terhadap variabel kemauan membayar pajak wajib pajak orang pribadi diketahui bahwa Pengetahuan dan Pemahaman Peraturan Perpajakan $\left(\mathrm{X}_{2}\right)$ mempunyai nilai signifkasi 0,031 yang berarti nilai ini lebih kecil dari 0.05 dengan $t$ hitung sebesar 2.202 dan $t$ tabel 1.664, $t$ hitung $>t$ tabel. berdasarkan hal tersebut disimpulkan bahwa secara parsial variabel pengetahuan dan pemahaman peraturan perpajakan berpengaruh secara signifikan terhadap kemauan membayar pajak wajib pajak orang pribadi di Kota Tomohon karena nilai signifikasi yang lebih kecil dari 0.05 dan $t$ hitung > t tabel.

Hasil penelitian menunjukkan bahwa pengetahuan dan pemahaman peraturan perpajakan berpengaruh secara signifikan terhadap kemauan membayar pajak Wajib Pajak Orang Pribadi di Kota Tomohon. Kurangnya pengetahuan dan pemahaman akan perpajakan merupakan salah satu penyebab rendahnya kemauan membayar pajak. Berdasarkan Hasil penelitian ini diharapkan dapat menjadi ajuan bagi petugas pajak untuk meningkatkan kemauan membayar pajak. Salah satu upaya yang dilakukan adalah melakukan penyuluhan dan sosialisasi perpajakan dikalangan masyarakat khususnya yang melakukan pekerjaan bebas. Sehingga petugas pajak bisa menjelaskan akan pentingnya membayar pajak kepada Negara dan sanksi yang akan diterima bila tidak membayar pajak. Serta memberikan training melaporkan dan membayar pajak yang mudah dipahami masyarakat luas dan cara mengisi SPT karena pengisian SPT merupakan salah satu faktor penghambat dalam membayar pajak karena belum cukup mengerti dalam pengisiannya.

\subsubsection{Pengaruh Kualitas Layanan terhadap Kemauan Membayar Pajak Wajib Pajak Orang Pribadi}

Berdasarkan hasil uji t yang dilakukan untuk melihat pengaruh kualitas terhadap variabel kemauan membayar pajak wajib pajak orang pribadi diketahui bahwa kualitas layanan $\left(\mathrm{X}_{4}\right)$ mempunyai nilai signifikasi 0,126 yang berarti nilai ini lebih besar dari 0.05 dengan $t$ hitung sebesar 1.548 dan t tabel 1.664, t hitung < t tabel. Berdasarkan hal tersebut disimpulkan bahwa secara parsial variabel kualitas layanan berpengaruh tetapi tidak signifikan terhadap kemauan membayar pajak wajib pajak orang pribadi di Kota Tomohon karena nilai signifikasi yang lebih besar dari 0.05 dan $\mathrm{t}$ hitung < t tabel.

Hasil penelitian untuk variabel ini menyatakan bahwa aparat pajak dituntut untuk memberikan pelayanan yang ramah,adil,dan tegas setiap saat kepada wajib pajak serta dapat memupuk kesadaran 
masyarakat tentang tanggung jawab membayar pajak.Wajib pajak dapat mengenal pajak dari pelayanan yang diberikan oleh aparat pajak. Untuk itu aparat pajak harus memiliki keterampilan untuk dapat memuaskan wajib pajak. Keterampilan yang harus dimiliki aparat pajak adalah kemampuan dalam berhubungan dengan orang lain dengan cara-cara yang baik menekankan pada pentingnya kualitas aparat pajak dalam memberikan pelayan kepada wajib pajak. Pelayanan yang diberikan oleh fiskus selama proses perpajakan berkaitan dengan sikap wajib pajak. Proses perpajakan melibatkan fiskus dan wajib pajak membuat pelayanan yang diberikan oleh fiskus turut membentuk sikap (atitude) wajib pajak dalam mengikuti proses perpajakan. Semakin baik pelayanan fiskus maka wajib pajak akan memilkik sikap yang positif terhadap proses perpajakan. Namun jika pelayanan fiskus tidak baik, hal itu akan membuat wajib pajak enggan untuk membayar pajak sesuai ketentuan yang berlaku.

Ada beberapa indikator bahwa pelayanan fiskus yang berkualitas dapat mempengaruhi kemauan untuk membayar pajak. Pertama,fiskus diharapkan memiliki kompetensi dalam arti memiliki keahlian, pengetahuan dan pengalaman dalam hal perpajakan,administrasi pajak dan perundangundangan perpajakan. Kedua,fiskus harus memiliki motivasi yang tinggi sebagai pelayan publik. Ketiga, Kantor Pelayanan Pajak (KPP) diharapkan perluasan tempat pelayanan terpadu (TPT). TPT dapat memudahkan pengawasan terhadap proses proses pelayanan yang diberikan kepada wajib pajak (Widayanti dan Nurlis, 2010 ).

\section{KESIMPULAN DAN SARAN \\ 6.1 Kesimpulan}

Berdasarkan hasil penelitian dan hasil analisis data yang telah dilakukan dapat disimpulkan bahwa :

1. Kesadaran membayar pajak $\left(\mathrm{X}_{1}\right)$ berpengaruh secara signifikan terhadap kemauan membayar pajak wajib pajak orang pribadi di Kota Tomohon.

2. Pengetahuan dan pemahaman peraturan perpajakan $\left(X_{2}\right)$ berpengaruh secara signifikan terhadap kemauan membayar pajak wajib pajak orang pribadi di Kota Tomohon.

3. Kualitas layanan $\left(X_{3}\right)$ berpengaruh tetapi tidak secara signifikan terhadap kemauan membayar pajak wajib pajak orang pribadi di Kota Tomohon.

\subsection{Saran}

Hasil penelitian mengungkapkan bahwa kesadaran membayar pajak dan kualitas layanan mempengaruhi kemauan membayar pajak orang pribadi, sehingga dapat menjadi bahan acuan petugas pajak untuk meningkatkan kemauan Wajib Pajak. Aparat pajak dituntut untuk memberikan pelayanan yang ramah, adil, dan tegas setiap saat kepada wajib pajak. Sanksi Hukum tentunya tidak lepas dari ketatatan membayar pajak. Karena Masih ada wajib pajak yang menunggu ditagih baru membayar pajak, seperti peraturan pajak pada periode lama.Sehingga sanksi hukum bagi mereka yang melanggar peraturan perpajakan harus lebih di pertegas dan diperjelas.

Penyuluhan tentang Self Assessment System juga perlu ditingkatkan untuk memberi pengetahuan tentang kemudahan Sistem pajak itu sendiri yaitu adanya $e$-filling, $e-S P T, e-N P W P, e-$ regristration, drop box dan e-banking.Dimana sistem ini memberikan kemudahan bagi Wajib Pajak.Penyuluhan atau sosialisasi rutin ataupun berupa pelatihan harus dilakukan secara intensif agar kesadaran masyarakat untuk membayar pajak dapat meningkat atau dapat lebih menumbuh kembangkan kesadaran dan tanggung jawab akan hak dan kewajiban sebagai Wajib Pajak. Untuk mewujudkan hal tersebut tentunya tidak lepas dari peran serta pemerintah dalam menjalankan kewajiban yaitu memberikan timbal balik yang sifatnya tidak langsung antara lain perwujudan dalam bentuk pembangunan berbagai sarana dan prasarana yang kegunaannya bukan secara individual tetapi ditunjukan untuk kepentingan umum.

Bagi penelitian lain diharapkan untuk menambah variabel lain yang dapat mempengaruhi kemauan membayar pajak dan sebaiknya dengan jumlah sampel yang lebih besar sehingga hasil penelitian memiliki daya generalisasi yang lebih kuat. 


\section{DAFTAR PUSTAKA}

Aini, Anindita Nur. 2012. Faktor - faktor yang mempengaruhi kemauan untuk membayar pajak bagi wajib pajak orang pribadi yang melakukan pekerjaan bebas dikabupaten blora. Surakarta : Universitas Muhammadiyah.

Anggraeni, Monica Dian. 2011. Pengaruh Pemanfaatan Fasilitas Perpajakan Sunset Policy Terhadap Tingkat Kepatuhan Wajib Pajak. Semarang : Universitas Diponegoro. eprints.undip.ac.id/29742/1/Skripsi008.pdf diakses tanggal 27 September tahun 2012.

Devano, S dan Siti Rahayu.2006. Perpajakan: Konsep, Teori, dan Isu, Kencana, Jakarta.

Direktorat Jenderal Pajak, 1983, "Undang-Undang Republik Indonesia No. 6 Tahun 1983, tentang Ketentuan Umum dan Tata Cara Perpajakan (KUP) sebagaimana telah diubah terakhir dengan UU No. 16 Tahun 2009".

Gozali, Imam. 2005. Aplikasi Analisis Multivariate dengan Program SPSS. Edisi 3. Semarang : Badan Penerbit Universitas Diponegoro.

Handayani, Sapti Wuri. 2011. Faktor - faktor yang mempengaruhi Kemauan Membayar Pajak Wajib Pajak Orang Pribadi yang melakukan Pekerjaan Bebas. Purwokerto: Universitas Jenderal Soedirman .

Hardiningsih, Pancawati. 2011. Faktor - faktor yang mempengaruhi kemauan membayar pajak . Semarang : Universitas Stikubank.

Hariyati, Nunuk .2010. Pengaruh kualitas layanan terhadao kepuasan wajib pajak (studi pada pelayanan pajak pratama Purbalingga). Malang : Universitas Negeri Malang.

Jatmiko, Agus Nugroho. 2006. Pengaruh Sikap Wajib Pajak pada Pelaksanaan Sanksi Denda, Pelayanan Fiskus dan Kesadaran Perpajakan terhadap Kepatuhan Wajib Pajak (Studi Empiris Terhadap Wajib Pajak Orang Pribadi di Kota Semarang). Semarang. Universitas Diponegoro.

Priyatno, Dwi. 2008. Mandiri Belajar SPSS. Mediakom; Yogyakarta.

Rantung, Tatiana Vanessa dan Priyo Hari Adi. 2009. Dampak program sunset policy terhadap faktor faktor yang mempengaruhi kemauan membayar pajak. Salatiga : Universitas Kristen Satya Wacana.

Sarjono, Haryadi \& Winda Julianita. 2011. SPSS vs LISREL Sebuah Pengantar, Aplikasi untuk Riset. Jakarta : Salemba Empat.

Setyonugroho, Hariyadi. 2012. Faktor-Faktor yang Mempengaruhi Kemauan untuk Membayar Pajak Wajib Pajak Orang Pribadi di KPP Pratama Surabaya Tegalsari. Surabaya : Sekolah Tinggi Ilmu Ekonomi Perbanas.

Siahaan, Marihot Pahala. 2010. Hukum Pajak Elementer Konsep Dasar Perpajakan Indonesia. Yogyakarta : Graha Ilmu.

Siti, Resmi. 2007. Perpajakan Teori dan Kasus, Dua, Salemba Empat ; Jakarta.

Soemitro Rochmat. 2007. Dasar-dasar Hukum Pajak dan Pajak Pendapatan; PT. Eresco, Bandung .

Sudjana, Nana. 2006. Dasar-Dasar Proses Belajar Mengajar. Sinar Baru Algensindo : Bandung.

Sugiyono .2007. Statistika Untuk Penelitian, Penerbit Alfabeta, Bandung.

Uma ,Sekaran. 2006. Metode Penelitian Bisnis. Salemba Empat. Jakarta.

Waluyo, 2012, Akuntansi Pajak, edisi 4, Salemba empat; Jakarta.

Waluyo, 2010, Perpajakan Indonesia, edisi 7, Salemba empat ;Jakarta.

Widayati. dan Nurlis. 2010. Faktor-Faktor Yang Mempengaruhi Kemauan Untuk Membayar Pajak

Wajib Pajak Orang Pribadi Yang Melakukan Pekerjaan Bebas (Studi Kasus Pada Kpp Pratama

Gambir Tiga), Makalah Simposium Nasional Akuntansi XIII. Purwokerto.

Widia, I Nyoman. 2009. Hukum Pajak. Purwokerto.

Widyaningsih, Aristanti. 2011. Hukum Pajak dan Perpajakan dengan Pendekatan Mind Map, Alfabeta.

Bnadung. 